\title{
A Faculdade de Direito e a reforma do ensino jurídico.
}

\author{
Menotti del Picchia \\ Da Academia Brasileira de Letras
}

\begin{abstract}
A nossa Faculdade de Direito - como a escola idêntica de Pernambuco - tem, na tradição da nossa cultura o prestígio que Cambridge, Harvard possuem entre os povos de fala inglêsa. Por mim, entretanto, penso que a cátedra pernambucana, com um Tobias Barreto revolucionando, no tempo, não com uma filosofia original mas com bravura reformista os rumos da nossa cultura, possuiu influência maior na libertação do pensamento brasileiro. A Faculdade de S. Paulo, porém, pelos gênios que iluminaram seu corpo discente, fica na história das Ietras e dos grandes movimentos nacionais - romantismo, abolição, república, revolução constitucionalista - como o mais glorioso foco espiritual da nação. Filhos de todos os Estados que se revelaram dos nossos maiores poetas, jurisconsultos e estadistas, ali encontraram clima para a eclosão dos seus talentos. Não foi mister haver uma grande voz nas cátedras para fazer êsses gênios inconformados como Castro Alves, Rui, Rodrigues Alves, Alvares de Azevedo, desferirem seus vôos semeando idéias e liberdades pelo Brasil. A Academia de São Paulo num conceito rígido da norma jurídica foi sempre austera, quase conservadora. Seu amor e respeito à lei deram ao direito que ensinava uma função mais de contenção, de estabilidade, que de dinamismo social. Talvez a tradição reinol de prevenção contra o inconformismo quase rebelde dos "mamelucos do
\end{abstract}


planalto" levasse a casa do direito a cristalizar uma rígida consciência de ordem jurídica austera e pouco plástica. A presença do soberano, gerador do direito colonial, projetou-se, mesmo depois da independência, pela sombra severa dos códigos manuelinos e filipinos. Contra o impulso explosivo e juvenil das gerações libertárias que glorificaram as arcadas, opôs-se o sentido disciplinador de um direito concebido mais como um policiamento ético da sociedade que como um disciplinador de vivas energias sociais que procuravam apenas, na norma legal, um conteúdo harmonizador para poderem expandir-se dentro da ordem num mundo nascente e virginal de descobertas técnicas e inéditos módulos de vida.

Orgulhoso de ter frequentado essa gloriosa Academia, senti sempre, porém, a necessidade de ver operar-se nela aquela sutil revolução que a colocaria como pioneira em tentar amadurecer as fórmulas embrionárias de um direito novo que repontava, espontâneo, de novos tipos de posse de terra, de iniciativas pioneiras, e de reflexos sociais em comunidades poligenéticas secretando formas originais da nossa espontânea democracia. A antiquada rigidez dos nossos programas reclamavam uma racionalização e um critério que modernizasse o escalonamento das disciplinas. Foi por isso que, num dêsses magníficos volumes que formam a série de "Revista da Faculdade de Direito", li a carta do prof. Braz de Souza Arruda sôbre a Reforma do Ensino Jurídico sugerindo o escalonamento das disciplinas num novo programa.

O direito é universal como essência mas é específico e local como forma de realização pragmática. A advertência de Eisenman de que o fato do seu ensino radicar-se profundamente na tradição pode emprestar-lhe uma rigidez que inibe a visão das transformações que êsse mesmo direito possa necessitar para exprimir melhor as necessidades do meio em que se desenvolve deve estar sempre presente. Sou um eterno reformista por imaginar que a revolução da técnica, hoje quase mágica, modifica as rela- 
ções das coisas, embora, em matéria jurídica seja mister um máximo de cautela ao dar-se um passo novo uma vez que todo o lógico funcionamento harmônico da vida social deve repousar no direito. Vale a pena ler e meditar a carta do prof. Braz Arruda. 